\title{
TOOLS FOR CREATING POSITIVE REPUTATION WITH CUSTOMERS FOR CHEMICAL INDUSTRIAL ENTERPRISES
}

\author{
Martina Jelinkova ${ }^{1}$, Hana Lostakova ${ }^{2}$, Eva Pakostova \\ Department of Economy and Management of Chemical and Food Industry, Faculty of \\ Chemical Technology, University of Pardubice, Studentská 95, Pardubice, Czech Republic \\ E-mails: ${ }^{1}$ martina.jelinkova@upce.cz (correspondingauthor); ${ }^{2}$ hana.lostakova@upce.cz
}

\begin{abstract}
The scientific literature claims that a positive reputation is based on the effective management of all elements of the so-called corporate identity, i.e. corporate philosophy, culture, design, product and communication. The aim of our qualitative research in three large chemical industrial enterprises in the Czech Republic was to identify which specific tools within their corporate identity the enterprises use and consider to be most effective for the creation of their positive reputation with customers. The result is a comprehensive overview of the tools for creating a positive reputation with customers, especially for large industrial enterprises, not only in the Czech Republic.
\end{abstract}

Keywords: corporate identity, reputation management, industrial enterprises, chemical industry.

JEL Classification: L14, L65, M31.

\section{Introduction}

Positive corporate reputation and its efficient construction is a very important topic often discussed at the scientific and management level. Gardberg (2017) observed a steady increase in the number of articles about corporate celebrity, corporate identity, corporate image, and corporate reputation over twenty years. The importance of this issue is growing with growing competition in the markets (Abimbola \& Vallaster, 2007), but it is important to note that the importance of reputation will be more sensitive for companies in certain sectors than elsewhere (Lauterbach \& Pajuste, 2017). For example, Burke (2011) argues that positive corporate reputation will greatly influence customer buying decisions, especially if there are only small differences in prices, quality and products in the market. Another important aspect underlining the importance of the company's positive reputation is the company's affiliation to the so-called socially sensitive sector, such as the arms industry, chemical industry, tobacco industry, production of alcoholic beverages, etc. (Tetrevova, 2017, 2018) Both the above-mentioned arguments, which speak of the great importance of reputation for the company, can also be found in the chemical industry. It is primarily large industrial companies producing basic chemicals that can only hardly distinguish their products by their properties, quality or price, and moreover, they are closely watched by the state and the public due to the very significant impact of their activities on the environment in particular.

There is a general consensus in professional literature that positive corporate reputation is becoming one of the most valuable corporate assets in today's markets, and especially in some industries. (Gibson, Gonzales, \& Castanon, 2006; Burke, 2011) A good reputation can lead to a number of strategic benefits, including the possibility of lowering company costs, charging premium rates, attracting employees and investors, creating barriers to competition (Walter, 2010), and better coping with crises (Schnietz \& Epstein, 2005). It is evident that positive reputation increases the likelihood that stakeholders will start to work with the company and seek to create valuable relationships with it (Rhee \& Haunschild, 2006). The prior positive reputation of the company is a key antecedent of the effectiveness of the corporate communication. (del Mar Garcia-De Los Salmones \& Perez, 2018) Since a positive reputation is reflected in the economic benefits for the company, companies are forced to build their own reputation and invest in it (Fang, 2005). However, the range of specific tools for building a positive corporate reputation is very broad and difficult to map comprehensively. It can be assumed that the tools that can 
be used to create or strengthen positive corporate reputation are specific to different groups of corporate stakeholders and that they also vary according to different industries. To further the understanding of this issue in the chemical industry, we carried out a research, the results of which are presented in this paper.

\section{Theoretical Framework}

\subsection{Definition of corporate reputation}

Based on the study of literature, it can be stated that identifying a uniform, universally recognized definition of corporate reputation is a long-term problem (Wartick, 2002; Barnett, Jermier, \& Lafferty, 2006; Podnar \& Gobol, 2017). This statement was also supported by Walter (2010), who analyzed 43 papers on corporate reputation in his article A Systematic Review of the Corporate Reputation Literature (the sample of publications included only very frequently quoted articles from the field). Surprisingly, it was found that only 19 publications out of a total of 43 contained a definition of corporate reputation. Of the 19 publications mentioned, five (26 percent) referred to Fombrun (1996). Other definitions of reputation were not repeated. Thus, it can be stated that Fombrun's definition of corporate reputation can traditionally be regarded as fundamental when we often find its abridged version in the literature when Fombrun (1996) claims that reputation can be characterized as the overall estimation in which a particular company is held by its various constituents. The definition developed by Fombrun (1996) views corporate reputation as a perceptual representation of a company's past actions and future prospects that describes the firm's overall appeal to all of its key constituents when compared with other leading rivals. In Fombrunov's definition (1996), three key attributes can be emphasized: (1) reputation is based on perception; (2) it is a summary of the perception of all stakeholders; and (3) it is based on comparison (Brown \& Longsdon, 1997; Wartick, 2002). Some more recent definitions of reputation do not emphasize the aspect of comparison when Zyglidoupoulos (2005) defines, for example, reputation as the set of knowledge and emotions held by various stakeholder groups concerning aspect of a firm and its activities. Brown, Dacin, Pratt, \& Whetten, (2006) also view the nature of reputation in a similar way as they claim that the company's reputation is observer's collective judgments of a corporation based on assessments of the financial, social, and environmental impacts attributed to the corporate over time. Many authors agree with the definitions, such as Walter (2010) and Herrison (2013).

Based on the above definitions, it is possible to state that corporate reputation represents an aggregate or overall evaluation of a company by groups of individuals that exceeds the evaluation of specific features or attributes. (Burke, 2011) It is an inimitable, abstract, multidimensional (i.e. multidimensional) concept (Jarvinen \& Suomi, 2011) that can be described through its individual measurable dimensions (Agarwal, Osiyevskyy, \& Feldman, 2015). Based on their reputation, companies can also be compared and evaluated. (Dowling, 2004).

\subsection{Building a positive company reputation}

A set of activities that aim to build and maintain a positive corporate reputation is referred to as Reputation Management. Doorley and Garcia (2015) define it as a long-term strategy for measuring, controlling and managing the company's reputation as an asset. Its essence is a strategic plan to approximate corporate reputation to corporate identity. The goal is to create positive experiences and to present a desirable corporate identity. It can be said that the basic and most important tool for building a positive corporate reputation is the corporate identity, which must then be presented in an effective way to the company's stakeholders. The advocates of this opinion include Svoboda (2009), Vysekalova and Mikes (2009) Doorley and Garcia (2015) and Agarwal et al. (2015).

The definition published by Whetten and Mackey (2002) that claim that corporate identity is "that which is central, enduring, and distinctive about an organization" can be considered the basic definition of corporate identity. It is, therefore, the hidden "core" or the basic character of the company - i.e. the central and lasting qualities that define the company and distinguish it from other companies (Barnett et al., 2006; Fombrun \& van Riel, 2004). Barnett et al. (2006) describe corporate identity as a set of material and behavioural symbols and corresponding systems of belief, values and basic assumptions.

In the search for resources to create a positive corporate reputation based on a corporate identity analysis, it is important to identify its individual components. Here, however, there is no unambiguous agreement among experts. For example, 
Svoboda (2009) places corporate design and corporate communication among the basic means of corporate identity. Veber (2000) adds corporate culture and product to corporate identity attributes. Vysekalova and Mikes (2009) perceive components of corporate identity in a similar way. The authors assert that corporate identity has long been shaped by the company's culture and style (design), the way of communication, the behaviour and the atmosphere in the company. Increasing the company reputation is the most often mentioned benefit of Corporate Social Responsibility implementation. (Munzarova, Vavra, \& Havlickova, 2017). Also important is the design supply system of which the company is a part. (Vlckova, 2016). Striss and Vodak (2005) further add that corporate identity is also shaped by the company's philosophy. Based on the views of the authors, it can be stated that corporate identity can be created and directed by corporate philosophy, corporate culture, corporate design, marketing communication and product management. These tools are then supplemented and intertwined in practice. Obviously, if a company wants to build and maintain its positive reputation, it must devote itself to all these tools of corporate identity. In addition, brand identity should be considered evolving and able to change over time (Voyer, Kastanakis, \& Rhode, 2017). Identity can remain relatively stable and consistent over time, yet it can and does change - in particular within congruence of corporate identity meanings and signals over time. (Flint, Signori, \& Golicic, 2018) Based on an open dialogue with stakeholders, a trustworthy and authentic identity should then be created (Theunissen, 2014). This is the only way to build a positive reputation in the long term.

Since corporate reputation is perceived differently by different corporate stakeholders, it can be assumed that different tools for building a positive corporate reputation will be important for different stakeholder groups. So far, we have not found any studies in the professional literature specifying tools for creating a positive corporate reputation for different stakeholder groups. Our primary research effort was to identify the specific tools involved in building a positive corporate reputation for the company's customers, i.e. a specific and key group of the company's stakeholders. To do so, we based our work on an analysis of corporate identity, divided into corporate philosophy, culture, design, product and communication (see Figure 1).

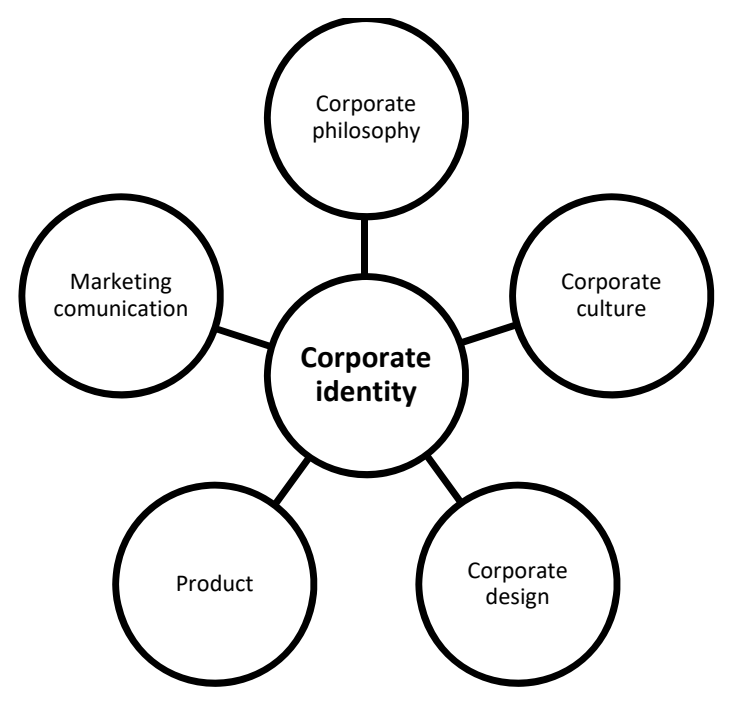

Figure 1. Corporate Identity Components (source: author)

Within these categories, we then looked for specific tools that are important for creating a positive customer reputation. The research was conducted on a sample of three large chemical companies in the Czech Republic.

\section{Researching the tools used by chemical companies to build their positive reputation with customers}

\subsection{Specification of primary research}

The primary qualitative research was carried out through the method of in-depth interviews with senior managers of the sales, marketing and PR departments of the monitored companies. Selected for the in-depth research were three major chemical industrial companies operating in the Czech Republic, but applying their products on international markets. The companies were selected by a method of deliberate selection so that each of them was a representative of one of the areas of the chemical industry - technical chemistry, petrochemistry and synthetic materials. Due to the confidential nature of the information communicated, the results of the research are presented without specifying the companies surveyed.

In each company, about 10 interviews with selected executives were carried out during 2017. In particular, they were employees of retail, sales and marketing departments, i.e. those who are in direct contact with customers. The interviews were also attended by representatives of the press and PR departments of the monitored companies. These were semi-structured interviews with open 
questions where a detailed interviewing scenario included over 50 open questions. Each interview lasted about 1 hour and 30 minutes. A detailed research report was written from each interview, averaging about 10 pages. With regard to the type of research, it was not appropriate to process the data statistically. A thorough factual content analysis was carried out that made it possible to analyze the various tools for building a positive reputation of the monitored companies towards their customers, which are presented below.

\subsection{Processing and analysis of research results}

An initial interesting finding in our research was that the employees of the companies surveyed perceive the concept of corporate reputation as almost identical to the corporate image. A certain nuance of the concepts is seen by the interviewed managers in that they understand the corporate image as the company's behaviour and the corporate reputation as a reflection of this behaviour in the eyes of the stakeholders. While this does not match the definitions of the image where the image is perceived as a reflection of the company's behaviour in the minds of the stakeholders (e.g. Veber, 2000; Foret, 2013 etc.), it points to an interesting difference in the use of these terms in corporate practice.

While the companies surveyed seek to make their reputation positive in the eyes of all stakeholders, they put slightly less emphasis on creating a positive reputation for competitors, central government bodies (government, ministries, etc.), state administration and self-government bodies and financial institutions (e.g. banks, insurance companies, etc.) The managers interviewed believe that they are successful in creating a positive reputation for important groups of stakeholder, in particular through the following tools:

- Distributors - what matters is a personal approach, fair conduct, the right price.

- Shareholders - positive reputation is supported by open professional communication, good financial results and profit making.

- Professional public - the companies hold professional events and conferences, publish expert papers, hold open discussions with experts.

- The local community (residents of the region) - in particular, they value opendoor days, sponsoring local sports and cultural events, information on ecological investments, more environmentally-friendly operation, and encouraging a positive view of chemistry.

- General public - good communication through websites, social networks and media (such as press releases and conferences), as well as sponsorship and open days are important. The effort of companies is to educate the public and reduce the negative perception of chemistry as such.

- Educational institutions - the companies endeavour to provide educational institutions as much support as possible. They organize excursions, chemistry courses for high school students, offer temporary jobs, internships, trainee programmes, collaborate with universities on research and development. They also offer jobs for fresh graduates.

- Media - the companies collaborate with local media, especially with the press. They seek to offer interesting topics to the media.

- Civic associations and movements - the companies mainly sponsor various nonprofit and charity organizations, rescue shelters, etc.

While central state authorities, state administration and self-government authorities and financial institutions are not crucial to the initiative of the companies surveyed to build their positive reputation, the companies are aware that the positive reputation of these stakeholders can be built notably by respecting laws, standards, regular inspections, audits, annual reports, and open communications. On the other hand, in terms of building a positive reputation, it is customers (both key and others) that the surveyed companies consider the most important of all stakeholders. That is why we paid extraordinary attention to this group of stakeholders in our research.

All of the surveyed companies really care about its positive reputation among their key customers as well as other customers. The companies believe that they currently have a positive reputation with their present and potential customers, among other things thanks to their long-standing tradition in the market.

Based on the opinion of the surveyed employees of the surveyed enterprises, the following order of the individual aggregate attributes involved in creating a positive corporate 
reputetion in the eyes of the corporate customers $(1$ - the most important, 5 - the least important of the monitored areas) can be determined:

1. Method of customer service.

2. Company's supply (products, price).

3. Company's philosophy and culture (i.e. attitudes, values and standards shared by its employees).

4. Marketing communication.

5. Corporate design (see the definition above).

In turn, we will deal with the individual attributes of creating a positive corporate reputation in more detail.

Promoting a positive corporate reputation towards customers through a product (products and services), i.e. through customer service

The surveyed companies report that they have a positive reputation with their customers especially thanks to the quality of their products, their individual approach to customers, the flexibility and quality of their services, especially logistics.

According to the interviewed employees of all the surveyed companies, the following factors contribute to the positive reputation with customers in terms of supply and customer service:

- Product quality and its stability.

- Quality of service.

- The speed of delivery.

- Faultless delivery.

- Individual approach to customers.

- Ability to flexibly respond to customer wishes.

- Compliance with contractual terms.

- ISO Certification - strict internal standards.

- Strict adherence to standards and regulations.

- Forthcoming approach to customer audits.

- Personal relationships with customers.

- Support system for existing customers.

Factors in the field of customer service were also identified, which, according to the respondents, tend to contribute or greatly contribute to the positive reputation of the company with its customers. According to the respondents, they include:

- The range of products and services.

- Quality of staff.

- Innovation according to customer needs.

- Seamless collaboration between supplier and distributors.
According to some respondents, the following factors also play a part in creating a positive reputation of the company with its customers:

- Reasonable prices and favourable payment terms.

- Customer awareness of the cooperation of a supplier company with renowned business partners.

Other significant customer service areas that are critical to creating a positive reputation of the company for its customers were not identified. According to the companies surveyed, the greatest danger in terms of damaging the positive reputation with customers is related to quality fluctuations that need to be resolved by complaints (e.g. packaging complaints) or damage to the reputation due to the influence of the media e.g. information on injuries to employees in the company. The biggest drawbacks are seen by all the companies under review in their ability to innovate in line with customer needs.

\section{Promoting a positive corporate reputation to- wards customers through corporate philosophy and culture}

Representatives of all the companies surveyed say that the presentation of corporate philosophy (i.e. in the company's shared fundamental principles and values indicating the direction of the business), as well as the communication of the mission, vision and long-term goals of the company contribute to the positive reputation of the company in the eyes of the customers. In the interviewed companies, corporate philosophy attributes are presented mainly through their websites, social networks and blogs, but primarily through the practical application in dealing with customers. The companies admit that they have much space for improvement in terms of clear presentation of their corporate philosophy. In particular, one of the companies surveyed, which is managed by foreign owners within an association in the holding, sees a major problem in this area. The foreign management dictates to the company the form and way of communicating corporate philosophy, and, according to the respondents, does not correspond to the needs of the domestic market.

All the interviewed managers were able to define a single company motto that reflects the business principles that all employees of the company should follow. Mottos most often expressed the following principles: high quality, innovation and development, quality service, modernity, health protection, work safety and 
environmental care (eco-friendliness). While compliance with these principles can make a major contribution to the company's positive reputation with customers, it is often insufficiently presented to the employees of the company.

There is a fairly strong corporate culture in all of the companies under review, which is clearly supported by their management and manifested in an informal behaviour of the employees, but it is also supported by formally established codes or guidelines. The form and structure of the documents in question are an internal affair of the companies and their specific form is often adapted to the specific needs of the individual departments. There is an ethical code in all of the companies. Employees are regularly trained on codes and guidelines and the compliance thereof is monitored. Failure to comply with the formal principles of employee behaviour is sanctioned. The companies do not see any major problem in this area, but they are not a hundred percent convinced that this is a critical issue for customers.

Representatives of all the companies surveyed expressed unequivocally that in terms of positive corporate reputation with customers, the societal-ethical behaviour of the company was very important to all of its stakeholders. Interestingly, the respondents do not see any differences in the importance of individual areas of corporate social responsibility in the eyes of customers and consider environmental protection, employee care, business ethics, and charity or sponsorship activities as equally important to perceiving the positive reputation of the business with customers.

\section{Promoting a positive corporate reputation to- wards customers through marketing commu- nication}

All the companies surveyed use the following components of the marketing communication mix to communicate with their customers:

- Personal communication (face-to-face communication, but also via phone, email). The communication is provided mainly by the sales department, but also by assistants and the marketing staff. Communication is managed entirely individually according to the needs of specific customers. A problem can be traced in the case of rather exceptional ignorance of specific information by an employee, in the case of illness or holidays of responsible staff with the knowledge of the needs of individual customers. Minor difficulties are also caused by time zone differences between the Czech Republic and abroad. In the opinion of the respondents, the given method of communication certainly contributes to the positive reputation of the company in the perception of its customers.

- Classic advertising (it is disseminated in a non-directed way primarily through media and is without the possibility of immediate feedback). As part of the classic advertising, the companies under review use advertisements in professsional journals, advertisements on the Internet as well as professional portals. Exceptionally, for products designed for the $\mathrm{B} 2 \mathrm{C}$ market, radio advertising is also used. It can be said that the given way of communication is not at the centre of interest of the monitored companies, also owing to the difficult-to-estimate efficiency in B2B markets. The respondents acknowledge its importance, in particular, for the overall visibility of the company on the market, but they see no reason to invest more in this form of communication.

- Direct advertising (can be disseminated directly, there is the possibility of immediate feedback). The companies under review, in the context of this element of the marketing communication mix, use, in particular, bills of sale or catalogues, e-mails, websites. The representatives of the companies surveyed believe that direct advertising contributes to the positive reputation of their business mainly by facilitating customer orientation in the supply. From this point of view, the graphic layout and overview of the range of products on the websites of the companies surveyed are problematic, which most of the respondents consider being inadequate.

- Sales promotion (usually time-limited offers to support sales). The most frequently used sales promotion tools in the companies surveyed include participation in fairs and exhibitions and product sampling. According to respondents, this is an important visibility tool for customers. 
- Public Relations - Representatives of the companies surveyed said that it is, in particular, the following public relations tools that influence the perceived reputation of the company with corporate clients: press releases, press conferences, occasional publications, presentations, company web presentation, sponsorship and CSR activities. In terms of creating a positive reputation with customers, however, the interviewed employees do not see any significant influence.

The companies surveyed are trying to be innovative in terms of marketing communication, which in the opinion of the respondents contributes to the positive perception of the company with their customers. The companies use social networks, including Facebook and LinkedIn, as well as YouTube, a corporate TV channel, and one of the companies said they were filming their promo announcements using a drone. The companies see the future in particular in expanding online communication, interactivity and Skype business.

Based on the experience of the interviewed managers, we can state that customers value most the accuracy, creativity, rationality, information value, availability at the right time, adequacy, online access and personal approach from the supply company within the marketing communications.

Promoting a positive corporate reputation towards customers through corporate design

All of the companies surveyed use a unified visual style to a certain extent. The visual style is unified in terms of corporate vehicles, office equipment, promotional materials, packaging, promotional items, presentation materials, printed documents, marking of buildings, business cards and envelopes. Uniform are the logo, colours, style of letters, slogan and headers of official documents. The companies usually have a dress code that is not strictly adhered to. All of the companies under review have a trademarked logo. Exceptionally, product labels and slogans are also protected by law (only for products intended for the B2C market). The unified visual style of the companies surveyed is supported by a design manual, a graphic manual and a logo manual, the use of which is without any problems. The managers interviewed perceive a uniform visual style as an important tool to support customer orientation; however, in terms of promoting positive customer reputation, this is not a key issue.

\section{Conclusions}

Positive customer reputation is an important aspect contributing to the development of supplier-customer relationships. Strong and loyalties created are an irreplaceable and impossible-to-copy competitive advantage. That is why companies in today's markets are constantly looking for the most effective way to create, develop and maintain their positive reputation. The mapping of the issue in the context of creating a positive reputation for chemical industry companies with its customers was the primary focus of our primary research.

Considering that the available professional literature does not provide us with a comprehensive list of tools suitable for building a positive reputation for companies specifically towards individual types of stakeholders, the research conducted can be considered a significant contribution to the issue. The specified tools that are important for creating a positive reputation with the companies' customers are a primary step in creating a comprehensive theoretical methodology of creating a positive corporate reputation for key stakeholders. Creating this comprehensive methodology is our goal and will also serve as a guideline in conducting follow-up research.

From the point of view of managerial practice, the research results can be used for drawing significant inspirations, setting priorities and revealing possible pitfalls that industrial enterprises can encounter in their efforts to build a positive reputation with their customers. The major sources for creating a positive reputation with customers can be sought by large industrial companies especially in the following areas:

- Quality, flawless, fast, flexible and individual customer service.

- Presentation of corporate philosophy, including the mission, vision, and longterm business goals.

- The socio-ethical behaviour of the company.

- Individual, especially personal communication with corporate customers.

The biggest deficiencies in terms of developing their positive reputation with customers are seen by the companies concerned in these aspects:

- Inability to innovate the supply in line with customer needs. 
- The incorrect way of presenting corporate philosophy.

- Non-uniformity of corporate design.

- Poor arrangement of the corporate website.

- Lack of funding for more effective marketing communication.

In conclusion, it is important to note that the research carried out mapped the issue in depth, but only on a very limited sample of industrial companies. We are currently preparing extensive quantitative research to verify the validity of the hypotheses resulting from the findings of the present survey on a wider sample of industrial companies.

\section{References}

Abimbola, T., \& Vallaster, C. (2007). Brand, organisational identity and reputation in SMEs: An overview. Qualitative Market Research, 10(4), 341-348. https://doi.org/10.1108/13522750710819685

Agarwal, J., Osiyevskyy, O., \& Feldman, P. M. (2015). Corporate reputation measurement: alternative factor structures, nomological validity, and organizational outcomes. Journal of Business Ethics, 130(2), 485506. https://doi.org/10.1007/s10551-014-2232-6

Barnett, M. L., Jermier, J. M., \& Lafferty, B. A. (2006). Corporate reputation: The definitional landscape. Corporate Reputation Review, 9(1), 26-38. https://doi.org/10.1057/palgrave.crr.1550012

Brown, B., \& Logsdon, J. M. (1997). Factors influencing Fortune's corporate reputation for "community and environmental responsibility". In Weber, J., \& Rehbein, K., Proceedings of the Eighth Annual Meeting of the International Association for Business and Society (pp. 184-189), June 1998. Destin, FT. https://doi.org/10.5840/iabsproc1997836

Brown, T. J., Dacin, P. A., Pratt, M. G., \& Whetten, D. (2006). Identity, intended image, construed image, and reputation: An interdisciplinary frameworkmand suggested terminology. Academy of Marketing Journal, 3(2), 99-106. https://doi.org/10.1177/0092070305284969

Burke, R. J. (2011). Corporate reputations: Development, maintenance, change and repair. Burlington, VT: Gower. eBook.

del Mar Garcia-De los Salmones, M., \& Perez, A. (2018). Effectiveness of CSR advertising: The role of reputation, consumer attributions, and emotions. Corporate Social Responsibility and Environmental Management, 25(2), 194-208. https://doi.org/10.1002/csr.1453

Doorley, J., \& Garcia, H. F. (2015). Reputation management: the key to successful public relations and corporate communication ( $3^{\text {rd }}$ ed.). New York: Routledge, Taylor \& Francis Group.

Dowling, G. R. (2004). Corporate reputations: Should you compete on yours?. California Management Rewiew, 46(3), 19-36. https://doi.org/10.2307/41166219

Fang, L. H. (2005). Investment bank reputation and the price and quality of underwriting services. The Journal of Finance, 60(6), 2729-2761.

https://doi.org/10.1111/j.1540-6261.2005.00815.x
Flint, J. D., Signori, P., \& Golicic, S. L. (2018). Corporate identity congruence: A meanings-based analysis. Journal of Business Research, 86(2018, May), 68-82. https://doi.org/10.1016/j.jbusres.2018.01.052

Fombrun, C. J., \& van Riel, C. B. M. (2004). Fame \& fortune: How successful companies build winning reputations $\left(1^{\text {st }}\right.$ ed.). New York: Financial Times Prentice-Hall.

Fombrun, C. J. (1996). Reputation: Realizing value from the corporate image ( $1^{\text {st }}$ ed.). Boston: Harvard Business School Press.

Foret, M. (2013). Marketing communication in public administration ( $1^{\text {st }}$ ed.). Brno: ASTRON studio CZ.

Gardberg, N. A. (2017). Corporate reputation: Fashion, fad, or phenomenon?. Corporate Reputation Review, 20(34), 177-180Gibson, D., Gonzales, J. L., \& Castanon, J. (2006). The importance of reputation and the role of public relations. Public Relations Quarterly, 51(3), 1518. https://doi.org/10.1057/s41299-017-0033-4

Herrison, K. (2013). Why a good corporate reputation is vital to your organization. Retrieved from http://www. cuttingedgepr.com/articles/corprep_important.asp

Jarvinen, R., \& Suomi, K. (2011). Reputation attributes in retailing services: managerial perspective. Managing Service Quality, 21(4), 410-423. https://doi.org/10.1108/09604521111146270

Lauterbach, B., \& Pajuste, A. (2017). The media and firm reputation roles in corporate governance improvements: Lessons from European dual class share unifications. Israeli Corporate Governance, 25(1), 419. https://doi.org/10.1111/corg. 12153

Munzarova, S., Vavra, J., \& Havlickova, M. (2017). Motivation, activities and bariers of the corporate social responsibility implementation in the Czech SME Manufacturing company. In Modern Science Conference Proceedings SGEM2017, Book 1(V), 681-688. https://doi.org/10.5593/sgemsocial2017/15/S05.086

Podnar, K., \& Gobol, U. (2017). The Quest for the corporate reputation definition: Lessons from the interconnection model of identity, image, and reputation. Corporate Reputation Review, 20(3-4), 186-192. https://doi.org/10.1057/s41299-017-0027-2

Rhee, M., \& Haunschild, P. R. (2006). The liability of good reputation: A study of product recalls in the U.S. automobile industry. Organization Science, 17(1), 101117. https://doi.org/10.1287/orsc. 1050.0175

Schnietz, K., \& Epstein, M. (2005). Exploring the financial value of a reputation for corporate social responsibility during a crisis. Corporate Reputation Review, 7(4), 327-345. https://doi.org/10.1057/palgrave.crr.1540230

Striss, J., \& Vodak, J. (2005). Corporate identity as one of the important management activity ( $1^{\text {st }}$ ed.). Zilina: University of Zilina.

Svoboda, V. (2009). Public relations: moderně a účinně (2 $2^{\text {nd }}$ ed.). Praha: Grada.

Tetrevova, L. (2017). Komunikování společensky odpovědných aktivit cukrovarnickými podniky. Listy cukrovarnické a řepařské, 133(12), 394-396.

Tetrevova, L. (2018). Communicating socially responsible activities of chemical companies in the Czech Republic. Chemické listy, 112(2), 122-127.

Theunissen, P. (2014). Co-creating corporate identity through dialogue: A pilot study. Public Relations Review, 40(3), 612-614.

https://doi.org/10.1016/j.pubrev.2014.02.026 
Veber, J. (2000). Management: základy, prosperita, globalizace $\left(1^{\text {st }}\right.$ ed.). Praha: Management Press.

Vlckova, V. (2016, May). Assessment of cooperation within chosen supply system in the Czech chemical industry. In $9^{\text {th }}$ International Scientific Conference Business and Management, Vilnius, Lithuania. https://doi.org/10.3846/bm.2016.21

Voyer, B. G., Kastanakis, M. N., \& Rhode, A. K. (2017). Cocreating stakeholder and brand identities: A crosscultural consumer perspective. Journal of Business Research, 70(4), 399-410. https://doi.org/10.1016/j.jbusres.2016.07.010

Vysekalova, J., \& Mikes, J. (2009). Image a firemní identita ( $1^{\text {st }}$ ed.). Praha: Grada.
Walter, K. A. (2010). Systematic review of the corporate reputation literature: Definition, measurement, and theory. Corporate Reputation Review, 12(4), 357-387.

Wartick, S. (2002). Measuring corporate reputation: Definition and data. Business and Society, 41(4), 371-392. https://doi.org/10.1177/0007650302238774

Whetten, D. A., \& Mackey, A. (2002). A social actor conception of organizational identity and its implications for the study of organizational reputation. Business and Society, 41(4), 393-414. https://doi.org/10.1177/0007650302238775

Zyglidopoulos, S. C. (2005). The impact of downsizing on corporate reputation. British Journal of Management, 16(3), 253-259.

https://doi.org/10.1111/j.1467-8551.2005.00460.x 